\title{
Sphingosine 1-phosphate activates the MAP3K1-JNK pathway to promote epithelial movement and morphogenesis
}

\author{
Jingjing Wang ${ }^{1}$, Maureen Mongan ${ }^{1}$, Jerold Chun ${ }^{2}$ and Ying Xia ${ }^{1 *}$ \\ ${ }^{1}$ Department of Environmental and Public Health Sciences, University of Cincinnati, College of \\ Medicine, Cincinnati, Ohio, 45267, USA and 2 Sanford Burnham Prebys Medical Discovery Institute, La \\ Jolla, California, 92037, USA \\ * Corresponding author: \\ Ying Xia, $\mathrm{PhD}$ \\ Department of Environmental and Public Health Sciences \\ University of Cincinnati, College of Medicine \\ 160 Panzeca Way \\ Cincinnati, $\mathrm{OH} 45267-0056$ \\ Phone, 513-558-0371
}

Running title: S1P-MAP3K1-JNK signaling in epithelial cells

Keywords: sphingosine 1-phosphate, MAP 3 Kinase 1, Jun N-terminal kinase, MAPK signaling, epithelial morphogenesis, murine keratinocyte line 


\begin{abstract}
MAP 3 kinase 1 (MAP3K1) plays an essential role in embryonic eyelid development. It regulates epithelial morphogenesis through the spatialtemporal activation of Jun $\mathrm{N}$-terminal kinases (JNKs), resulting in forward progression of the embryonic eyelid epithelial cells to enable eyelid closure. The developmental signals that activate the MAP3K1-JNK pathway are still unknown, mainly due to the lack of suitable keratinocyte lines to elucidate the mechanisms of pathway regulation. To address this deficiency, we developed a straightforward method for long-term culture of mouse keratinocytes in feeder-free conditions using $\mathrm{Ca}^{2+}$-free media. Cells grown under these conditions displayed characteristic basal epithelial morphology and keratin 14 expression, but did not form tight- or adherens-junctions. Increased extracellular $\mathrm{Ca}^{2+}$ levels restored the formation of cell-cell junctions. Using keratinocyte lines derived from wild type and Map3kl-deficient mice, we found that sphingosine 1-phosphate (S1P) activated the JNK-c-JUN pathways in a manner dependent on MAP3K1 kinase activity and that this MAP3K1mediated signaling led to epithelial cell migration. The in vivo roles of this pathway were examined through crossing of genetic mutant mice. Loss-offunction of the S1P receptor (S1pr) 2/3 became haploinsufficient only when combined with Map3kl and Jnkl mutations such that the compound mutants displayed eyelid closure defects, suggesting these gene products cooperated in eye morphogenesis. Results of this work establish the S1PR-MAP3K1-JNK pathway as a crucial signaling mechanism for epithelial cell movement and morphogenesis.
\end{abstract}

\section{Introduction}

Signal transduction through the mitogen-activated protein kinase (MAPK) pathways is a central mechanism that regulates cellular responses to extracellular stimuli (1). A typical MAPK pathway is comprised of a MAP3K, a MAP2K and a MAPK, in which the MAP3Ks define tissue-, cell type- and stimuli-specificity in MAPK activity (2). The MAP3K1, a serine/threonine protein kinase and a member of the MAP3K superfamily, plays diverse roles in immune system development and function, injury repair, vasculature remodeling and tumor progression (3-10). Additionally, studies in independent genetic mouse models reveal an essential role of MAP3K1 in eye development (11). Mice lacking the full-length or the kinase domain of MAP3K1, or those harboring a spontaneous mutation where a $27.5-\mathrm{kb}$ deletion on chromosome 13 resulting in the elimination of eight exons of the Map3k1 gene, exhibit an eye-open at birth (EOB) phenotype (12-14). These genetic data indicate that MAP3K1 and its kinase activity are essential for eye development.

The EOB defect is the result of impaired embryonic eyelid closure, a morphogenetic event common in mammalian eye development (15). In mouse embryogenesis, the opposing eyelids move forward and ultimately meet and fuse at embryonic day (E) 15 - E16, resulting in a closed eyelid covering the ocular surface (16-18). The eyelids remain closed at birth, serving as a protective barrier for the immature eye; they re-open at postnatal day (P) 14. The failure of eyelid closure is not life-threatening and the resultant phenotype is easy to detect, enabling the identification of the EOB defects in at least 160 genetic mutant strains (http://www.informatics.jax.org/mp/annotations/M $\mathrm{P}: 0001302)$. These mutant strains underscore the genetic complexity behind eyelid morphogenesis $(11,19)$. Since embryonic eyelid closure is driven by epithelial forward movement, the EOB mice have become convenient tools to delineate the molecular and signaling mechanisms of epithelial morphogenesis (20-23).

In epithelial cells of the embryonic eyelids, MAP3K1 mediates the phosphorylation and activation of the MKK4 MAP2Ks, which in turn activate the Jun N-terminimal kinase (JNK) MAPKs $(12,13,24-26)$. Molecular studies in cultured cells and genetic mutant mice have further identified RhoA, a small GTPase, as one of the upstream activators of the MAP3K1-JNK pathway $(27,28)$. A potent RhoA activator is sphingosine 1phosphate (S1P), a phospholipid signaling 
molecule (29,30). S1P is present abundantly in the circulation and specific tissues; it binds to and activates the S1P receptors (S1PRs), which are G protein coupled receptors (GPCRs) that in turn transmit the signals intracellularly to elicit biological responses (31-35). The S1P/S1PR signal is essential for embryonic eyelid closure, because simultaneous deletion of S1pr2 and S1pr3 genes leads to the EOB phenotype similar to that found in the Map3kl-null pups (36). The relationships between S1P and MAP3K1 signaling in eyelid development, however, are yet to be investigated.

While keratinocytes derived from genetic mutant mice are valuable tools to investigate the mechanisms of epithelial abnormalities, methods have been limited mostly to the use of primary cultures of murine keratinocytes (37-39). Here we report the long-term growth of murine epithelial cells in low-Ca ${ }^{2+}$ keratinocyte serum-free medium (KSFM) without the requirement of serum and feeder cells. The medium permitted the growth of a few clones to reach confluence. Cells derived from these clones can be subcultured for $>60$ passages, they express proliferation and basal keratinocyte markers, and can be induced to establish cell-cell junctions. The cells can also be stored in liquid nitrogen and recovered, and retain the same growth and passaging capacity of the parent clones. With this method, we derived cells from wild type and Map3kl-deficient mice and obtained an essentially endless supply of genetically-modified keratinocytes. These cells, together with genetic mutant mice, enabled the identification of S1P as the physiological stimulus that activates the MAP3K1-JNK pathway, leading to epithelial movement and embryonic eyelid closure.

\section{Results}

\section{Long-term mouse keratinocyte culture in media} with low extracellular calcium

Three commercial media: (i), the KSFM without $\mathrm{Ca}^{2+}\left(\mathrm{KSFM}_{-} \mathrm{Ca}^{2+}\right)$, (ii), the KSFM with $\mathrm{Ca}^{2+}$ $\left(\mathrm{KSFM}+\mathrm{Ca}^{2+}\right)$, and (iii), the defined KSFM (DKSFM), were evaluated in mouse keratinocyte culture. The KSFM+Ca ${ }^{2+}$ and $\mathrm{KSFM}-\mathrm{Ca}^{2+}$, containing the same growth factor supplements, were different only in $\mathrm{Ca}^{2+}$ concentration. The KSFM-Ca ${ }^{2+}$ contained trace amounts of calcium
(0.06 mM), a level $\sim 60 \%$ lower than the $\sim 0.15 \mathrm{mM}$ levels in $\mathrm{KSFM}+\mathrm{Ca}^{2+}$ and DKSFM (Fig. 1A).

The keratinocytes isolated fresh from newborn pups were attached well on collagen IV-coated plates, reproduced quickly and became confluent in 1-2 weeks in DKSFM and $\mathrm{KSFM}+\mathrm{Ca}^{2+}$ media. A majority of the cells displayed similar morphologies with regular and polygonal shapes (Fig. 1B). The cells grown in KSFM-Ca ${ }^{2+}$ medium, on the other hand, were relatively inefficient in attachment and growth; however, a few small cell clusters became visible by 1-2 weeks in culture (Fig. 1C). Some of these clusters continued to grow, forming large colonies in 1-2 months, and ultimately growing to confluence in a few months. These cells also displayed epithelial morphologies with polygonal shapes and regular dimensions. The colony-forming efficiency varied from batch to batch with an average efficiency of approximately $0.002 \%$.

Cells grown in either KSFM+Ca ${ }^{2+}$ or DKSFM were not easily amplified through passaging, consistent with the recognized challenges in mouse keratinocyte subculture (40-43). Cells in KSFM-Ca ${ }^{2+}$, in contrast, could be extensively amplified through passaging, up to 60 times, resulting in a $>10^{30}$-fold increase in cell number, and the longest culture was maintained up to 18 months. Following storage in liquid nitrogen, the cells retained the growth and expansion capacities.

The identity of these cells was characterized by the examination of keratinocyte-specific gene expression. The expression of Krt14, the basal keratinocyte gene, as well as other keratinocyte markers, such as $\mathrm{Krt15}$, Krt 8, Krt 18 and $\mathrm{Cdh}$, was robust in cells grown in $\mathrm{KSFM}-\mathrm{Ca}^{2+}, \mathrm{KSFM}+\mathrm{Ca}^{2+}$ and DKSFM (Figs. 1D and 1E). In contrast, the expression of these genes was almost undetectable in embryonic stem cells (ESCs) and fibroblasts. Immunostaining showed that cells grown in the different KSFM media exhibited similar K14 expression in cytosol and perinuclei (Fig. 1F). Hence, all three media support epidermal keratinocyte culture, but only the $\mathrm{KSFM}-\mathrm{Ca}^{2+}$ preferentially supports keratinocyte with long-term proliferative output.

Molecular characteristics of keratinocytes in long-term culture 
The proliferation potential of cells grown in KSFM$\mathrm{Ca}^{2+}$ was assessed by colony-forming efficiency (CFE) assays. The CFE varied between lines derived from mice of the same genetic background, ranging from $0.5-6 \%(\mathrm{~N}=6)$ (Table 1). The colonies displayed different shapes and sizes, and there was a notable correlation between CFE and the number of holoclone-like colonies, exhibiting uniform, round shapes, and compact cell contents (44)(Fig. 2A). All 6 lines had similar growth rates with an average doubling time of $5.2+/-1.2$ days (Fig. 2B). The doubling time decreased as the passage number increased (Fig. 2C and Fig. S1).

The sustained keratinocyte growth could be due to the selective enrichment of epidermal stem cells (45-48). We evaluated this possibility by examining the expression of epidermal stem cell markers and found that the expression of $C d 34, K r t 15, K r t 19$ and Sca-1 was not much different in cells grown in any of the three media (Fig. 3A). On the other hand, the expression of Krt10, a marker of outer-layer terminal epidermal differentiation, and Collal, encoding extracellular matrix proteins of the epidermis, were markedly less abundant in the $\mathrm{KSFM}_{-\mathrm{Ca}^{2+}}$ cells than the $\mathrm{KSFM}+\mathrm{Ca}^{2+}$ and DKSFM cells (Fig. 3B). Conversely, the expression of $\alpha 6$ integrin, a marker of long-term proliferative potential, and $T p 63$, a transcription factor and a marker for proliferative epithelial cells, was more abundant in the KSFM-Ca ${ }^{2+}$ cells (49-51) (Fig. 3C).

Cells grown in the KSFM-Ca ${ }^{2+}$ also had reduced expression of $C d h$, which encodes the E-Cadherin that mediates the formation of adherens junctions in basal keratinocytes (52) (Fig. 3C). Correspondingly, adherens junctions were detected by immunostaining in cells grown in DKSFM but not in $\mathrm{KSFM}^{-\mathrm{Ca}^{2+}}$ (Fig. 3D). The Zonula occludens-1 (ZO-1), component of the tight junctions that provide semipermeable barrier for ions and solutes of the epithelial tissues, was also present at the plasma membrane of cells in DKSFM, but absent in cells in KSFM-Ca ${ }^{2+}$ (Fig. 3D). To determine if higher extracellular calcium level were responsible for the formation of cell-cell junctions, we switched the growth medium from $\mathrm{KSFM}-\mathrm{Ca}^{2+}$ to either $\mathrm{KSFM}+\mathrm{Ca}^{2+}$ or DKSFM, resulting in an increase in calcium from $0.06 \mathrm{mM}$ to $0.15 \mathrm{mM}$. Growing in media with higher calcium for 2 days was sufficient to increase E-Cadherin expression and induce the formation of adherens and tight junctions (Figs. 4A and 4B).

\section{S1P activates the MAP3K1-JNK pathways}

To assess gene functions in the keratinocytes, we made keratinocyte lines with $\mathrm{KSFM}-\mathrm{Ca}^{2+}$ using cells isolated from wild type and Map3k ${ }^{4 K D}$ pups $(13,53)$. The genotypic differences did not affect keratinocyte morphology or marker gene expression (Fig. S2).

We have previously shown, in mouse ESCs, that MAP3K1 is responsible for JNK activation by lysophosphatidic acid (LPA), which, like S1P, is a phospholipid signaling molecule that binds to and activates specific G-protein coupled receptors on the plasma membrane (24). To determine if MAP3K1 mediates the phospholipid signaling in keratinocytes, we treated the wild type and Map $3 k 1^{\triangle K D / \triangle K D}$ cells with S1P and LPA and examined the phosphorylation of JNK, extracellular signal-regulated kinase (ERK) and p38 MAPKs. S1P and LPA induced a transient phosphorylation of JNK equally well in the wild type and the Map3k1 $1^{\triangle K D / \triangle K D}$ cells grown in KSFM$\mathrm{Ca}^{2+}$; however, they induced pJNK in the wild type but not the Map3k1 ${ }^{4 K D / \triangle K D}$ cells that were switched to DKSFM medium for $48 \mathrm{~h}$ (Figs. 5A-C). Correspondingly, the phosphorylation of c-Jun, the JNK downstream substrate, was strongly induced by S1P and LPA in the wild type, but not in the Map $3 k 1^{\triangle K D / \triangle K D}$ cells in DKSFM (Figs. 5B and 5D). The activation of ERK and p38, in contrast, was unaffected by Map $3 k l$ deficiency and the various growth medium conditions (Figs. 5B and 5C). Thus, MAP3K1 appears to be required for S1Pinduced JNK activation only in the DKSFM medium-adapted keratinocytes.

\section{The S1P-MAP3K1 pathway in epithelial cell movement and embryonic eyelid closure}

The biological effects of S1P are mediated by the cell-surface $\mathrm{G}$ protein-coupled $\mathrm{S} 1 \mathrm{P}$ receptors $(31,33)$. Of the five receptor subtypes, S1PR1, 2 and 3 are expressed ubiquitously (54). Recent genetic data have shown that two of these receptors, S1PR2 and S1PR3, are collectively required for embryonic eyelid closure. Homozygous deletion of the gene encoding either receptor has no apparent effect on eyelid development, but the S1pr $2^{--}$S1pr $3^{-/}$pups are born 
with an EOB defect (36). While these findings suggest that S1PR2- and S1PR3-mediated signalling are required for eyelid closure, the downstream effector pathways remain elusive.

MAP3K1 and S1PR2/S1PR3 are expressed in the same group of epithelial cells in developing eyelids $(13,36)$, leading us to interrogate their relationships in vivo. We crossed the Map3k1 $1^{+/ \Delta K D}$ and the S1pr2/S1pr3 mutant mice and examined the eyelid phenotypes in the newborn pups. While neither the $S 1 p r 2^{+-}{ }^{-} 1 p r 3^{-/-}$nor the Map3 $31^{+/ \Delta K D}$ offspring had the open eye defects, approximately $50 \%$ of the Slpr2 ${ }^{+/-}$Slpr $3^{-/-}$Map $3 k 1^{+/ \Delta K D}$ pups $(\mathrm{N}=6)$ displayed the EOB phenotype (Fig. 6A). We extended the genetic testing to evaluate the potential functional interplays between $S 1 p r$ and $J n k 1$. In the $S 1 p 2^{+/-}$ $S 1 p 3^{-/}$genetic background, deletion of one $J n k l$ allele caused EOB defects in $5 \%$ pups $(\mathrm{N}=22)$, whereas ablation of two $J n k l$ alleles resulted in $63 \%$ of the pups $(\mathrm{N}=16)$ having the defects (Fig. 6A). The combined haplo-insufficiency of the mutants support the idea that S1PR2/3, MAP3K1 and JNK1 act in the same pathway for embryonic eyelid development (55).

Embryonic eyelid closure is the result of morphogenetic movement of epithelial cells located at the developing eyelid margin (23). To examine if the S1P-MAP3K1 pathways were implicated in this movement, we performed the scratch wound healing assays with wild type and Map $3 k 1^{\triangle K D / \Delta K D}$ keratinocytes. Addition of S1P to the wounded cells accelerated wound closure at similar rates, regardless of the Map3kl genotype, in cells grown in $\mathrm{KSFM}-\mathrm{Ca}^{2+}$; however, it enhanced wound closure in wild type, but not Map3k1 ${ }^{\triangle K D}$ cells switched to the DKSFM (Fig. 6C). Correspondingly, the lamellipodia-like F-actin protrusion was detected at the leading edge of the wounded wild type cells, but was absent in that of Map $3 k 1^{\Delta K D / \Delta K D}$ keratinocytes (Fig. 6D).

\section{Discussion}

In this study, we identify the S1P/S1PR-MAP3K1 pathway as a key signaling mechanism in epithelial movement for eyelid morphogenesis. Genetic data

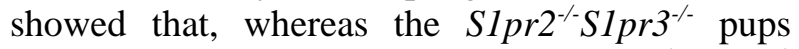
displayed the EOB phenotype, the S1pr2 ${ }^{+-} S 1 p r 3^{-/}$ pups had normal eyelid development, suggesting a single S1pr2 allele is sufficient for normal eyelid morphogenesis. The single S1pr2 allele, however, became inadequate when the Map3kl was heterozygous, and up to $50 \%$ of the S1pr2 ${ }^{+-}$S1pr3 ${ }^{\prime} M a p 3 k 1^{+/ \Delta K D}$ pups exhibited the EOB defects. Similar to previous findings that $J n k l^{-/}$acts in synergy with $M a p 3 k 1^{+/ \triangle K D}$ to cause the EOB phenotype (26), we found that Jnkl loss-offunction and S1pr2 ${ }^{+/-} \mathrm{Slpr}^{-/}$also exhibited haploinsufficiency. Furthermore, Jnkl appears to contribute to eyelid closure signaling in a gene dose-dependent fashion, as loss of one Jnkl allele caused 5\% EOB defects, and loss of two Jnkl alleles caused $63 \%$ EOB defects in the $S 1 p r 2^{+/}$ S1pr $3^{--}$backgrounds. Together, the non-allelic non-complementation displayed by SIpr2/3, Map $3 k 1$ and $J n k 1$ suggests that these gene products functionally interact and contribute to the same biological pathway (55). Supporting the suggestion, in vitro studies in keratinocytes show that $\mathrm{S} 1 \mathrm{P}$ is an extracellular cue that elicits a strong and rapid JNK activation mediated through MAP3K1. The S1Pinduced MAP3K1-JNK pathway leads to accelerated epithelial movement, a cellular activity crucial for embryonic eyelid closure.

To date, long-term culture of mouse keratinocytes has remained a practical challenge. We report an experimental protocol for growing keratinocytes with extensive proliferative capacity. There are some procedures reported in the literature that involve multiple subcultures of murine keratinocytes (56-61). In comparison, our straightforward approach does not require a feeder layer nor conditioned medium or pre-selection and enrichment of a targeted subpopulation; it supports keratinocytes with exceedingly strong proliferation potential, allowing at least 60 passages. Keratinocytes grown under low- $\mathrm{Ca}^{2+}$ conditions, however, lacked adherens and tight junctions. When increased extracellular calcium, these cells restored cell-cell junctions and become responsive to S1P in activating the MAP3K1 pathway. The experimental approach described here enables the easy growth and subculture of keratinocytes derived from mice and promises an endless supply of genetically modified keratinocytes.

Of the three commercial keratinocyte media tested, only the $\mathrm{KSFM}-\mathrm{Ca}^{2+}$ with $0.06 \mathrm{mM}$ calcium supported long-term keratinocyte culture. In vivo, low $\mathrm{Ca}^{2+}$ concentrations are found in the inner basal 
layer of the epidermis, where epithelial cell proliferation and maintenance of homeostasis take place, whereas high $\mathrm{Ca}^{2+}$ concentrations are present in the outer suprabasal layers associated with increased keratinocyte terminal differentiation (62). The low $\mathrm{Ca}^{2+}$ conditions also seem to favor proliferation while prevent differentiation in vitro, because keratinocytes in $\mathrm{KSFM}-\mathrm{Ca}^{2+}$ displayed increased proliferative markers, such Integrin $\alpha 6$ and p63, and decreased differentiation markers, such as K10. The proliferation capacity of the epidermis is attributed to progenitor, transient amplifying and stem cells, located in the interfollicular epidermis and the inner sheath of hair follicles (63-66). Our long-term cultured keratinocytes, however, did not have increased expression of selective stem cell markers, but had clonal expansion capacity. Given that the efficiency of generating the cell lines is relatively low, it is likely that the culture conditions described here selectively support a subset of epidermal progenitors, the molecular identities of which are yet to be fully understood.

As a phospholipid signaling molecule, S1P binds to and activates specific cell-surface GPCRs. The activated GPCRs in turn are coupled with heterotrimeric G-proteins to activate a range of downstream pathways, including AKT, RhoA, MAPK, and PLC (31). RhoA is a potential upstream activator of MAP3K1 because the active RhoA directly interacts with MAP3K1 (67) and RhoA loss-of-function delays eyelid closure in Map $3 k 1^{+/ \Delta K D}$ pups by 2 days (27). Nevertheless, the RhoA-null/Map $3 k 1^{+/ \triangle K D}$ eyelids eventually closed prenatally, and mutant pups were born with closed eyelids, suggesting RhoA makes a small contribution to MAP3K1 signaling. Moreover, we find that a chemical RhoA inhibitor only partially blocks S1P-induced JNK phosphorylation in keratinocytes (data not shown), suggesting other Rho family proteins, such as RhoB and RhoC, may play complementary roles in the transduction of S1P signals in MAP3K1 pathways.

Although LPA also activates the MAP3K1-JNK pathways in cultured keratinocytes, the LPA signaling appears to play little role in embryonic eyelid closure. LPA receptor null mice do not display an eyelid defect, and the presence of the LPA receptors does not rescue the EOB defects resulting from S1PR2/3 loss (68-71). It is reasonable to suggest that activation of the MAP3K1-JNK pathway by S1P is a developmental mechanism operative in a spatial-temporally specific fashion for eyelid morphogenetic closure (72). Whether this mechanism is implicated in other pathophysiological processes, such as tumor metastasis and inner ear development, where both the S1P receptors and the MAP3K1 play important roles, has become an intriguing open question (7,73-77).

A direct consequence of activating the S1PMAP3K1-JNK pathway is the phosphorylation of c-Jun, a transcription factor of the activating protein-1 (AP-1) family. JNK-mediated c-Jun phosphorylation at serine 63 and 73 results in a significant increase of c-Jun transcription activity (78-80). c-Jun and its target genes, such as heparinbinding EGF (HB-EGF), are indeed implicated in epithelial migration and embryonic eyelid closure (81-84). However, c-Jun 63/73 (AA) mutant mice display normal eye development (85), suggesting cJun phosphorylation is not required for embryonic eyelid closure. Furthermore, $c$-Jun and Map3k1 do not exhibit combined haploinsufficiency and their gene products are found in spatial-temporally separated cell populations in developing eyelids (86). On the other hand, JNK is known to carry out biological activities in a manner independent of cJun phosphorylation. For instance, JNK stimulates F-actin polymerization through the phosphorylation of paxillin, a focal adhesionassociated protein (87). This JNK activity leads to the formation of lamellipodia, major actin filament protrusions formed by migrating cells (88). In this context, we detected F-actin-enriched lamellipodia in S1P-treated wild type, not $\operatorname{Map} 3 k 1^{4 K D / \Delta K D}$, migrating keratinocytes.

Eyelid closure defects lead to ocular adnexal structure abnormalities in post-natal life $(89,90)$. The defective phenotypes resemble human congenital diseases, such as strabismus, ptosis and ectrodactyly-ectodermal dysplasia-cleft syndrome (91-94). The etiology and mechanisms for these diseases are still poorly understood. Data presented here suggest that abnormalities associated with defective eyelid closure could have polygenic etiology involving a combination of different genetic variants. Additionally, in utero exposure of 
the environmental toxicant dioxin induced the EOB phenotype in the Map $3 k 1^{+/ \Delta K D}$ but not wild type pups, presenting a case where the eye defects were the result of gene-environment interactions and multifactorial etiology (95). It is thus reasonable to surmise that inactivation of the S1P-MAP3K1-JNK pathways is a molecular mechanism through which genetic and environmental factors induce defective eyelid closure and related developmental disorders.

\section{Experimental procedures}

\section{Experimental animals}

Wild type and Map3k1 ${ }^{\triangle K D}$ mice were backcrossed with BL6 mice for at least 10 generations, as described before $(13,95)$. The Map $3 k 1^{\Delta K D / \triangle K D}$ pups displayed the EOB phenotype and their genotypes were confirmed by established PCR methods. The S1pr2 and S1pr3 mutants were crossed and genotyped as previously described (54). Newborn pups were used for the isolation of primary keratinocytes using procedures approved by the University of Cincinnati Animal Care and Use Committee.

\section{Chemicals, reagents and antibodies}

The 3 keratinocyte culture media used were KSFM$\mathrm{Ca}^{2+}$ (37010-022), KSFM+Ca ${ }^{2+}$ (17005-042) and DKSFM (10744019), from Gibco. TrypLE, 0.25\% Trypsin without EDTA and the trypsin inhibitor were also from Gibco. $\mathrm{CaCl}_{2}$ solution was from PromoCell; Collagen IV was from BD Biosciences Discovery, and S1P and LPA were from Cayman Chemical. The antibodies for phospho-JNK and phospho-ERK were purchased from Cell Signaling; anti-phospho-p38 was from Promega; and the anti$\beta$-Actin, calcium concentration kit, and Hoechst 33258 (for nuclei staining) were from Sigma. The anti-JNK antibody was obtained from Santa Cruz Biotechnology. Anti-ZO-1, anti-K14, Alexa fluor 594 phalloidin, anti-Rabbit Alexa Fluor 488 and anti-Mouse Alexa Fluor 594 were from Invitrogen, and anti-E-Cadherin was from BD Transduction Laboratories.

\section{Mouse keratinocyte culture}

Primary keratinocytes were isolated from newborn pups as described previously (38). Briefly, the epidermis was separated from dermis after overnight incubation in $0.25 \%$ trypsin, and placed in a tube containing $5 \mathrm{ml}$ media with $1 \mathrm{mg} / \mathrm{ml}$ trypsin inhibitor. After shaking the tube 50 times, large epidermal pieces were removed and the cells were centrifuged at $2000 \mathrm{rpm}$ for $5 \mathrm{~min}$. The cells were resuspended in the medium of choice and plated on collagen IV-coated plates at $>1 \times 10^{5}$ cells $/ \mathrm{cm}^{2}$. Cells were grown in a humidified $\mathrm{CO}_{2}$ incubator at $37{ }^{\circ} \mathrm{C}$ and refed every 2-3 days. Cells were passaged when reaching $90 \%$ confluence. For passaging, cells were rinsed with PBS, incubated with $0.05 \%$ EDTA in PBS for $10 \mathrm{~min}$ at $37{ }^{\circ} \mathrm{C}$, trypsinized twice in TrypLE for $10 \mathrm{~min}$ at $37^{\circ} \mathrm{C}$, and collected in media containing $1 \mathrm{mg} / \mathrm{ml}$ trypsin inhibitor. Cells were centrifuged; the pellets were then resuspended in the medium of choice and plated on collagen IV-coated dishes. For routine passage, cells were plated at $1-2.5 \times 10^{4} / \mathrm{cm}^{2}$.

For storage, cells dissociated from the culture dish were centrifuged as described above. The cell pellets were resuspended in $1 \mathrm{ml}$ culture medium containing $10 \%$ DMSO and stored in liquid $\mathrm{N}_{2}$. The frozen cells were recovered after thawing in a $37{ }^{\circ} \mathrm{C}$ water bath, washed once with growth medium, centrifuged, and the pellets resuspended and plated in a collagen IV-coated dish.

In some experiments, when cells grown in KSFM$\mathrm{Ca}^{2+}$ reached $>80 \%$ confluence, the media were changed to either $\mathrm{KSFM}-\mathrm{Ca}^{2+}$ plus $0.09 \mathrm{mM}$ calcium, $\mathrm{KSFM}+\mathrm{Ca}^{2+}$, or DKSFM, for 48 to $72 \mathrm{~h}$.

\section{Colony-forming efficiency (CFE) assays}

Cells were plated at $1-200 / \mathrm{cm}^{2}$ and cultured for 14 days. After culture, the medium was removed, cells were fixed with $4 \%$ PFA for 15 min, washed twice with PBS, and dried for $20 \mathrm{~min}$. The cells were stained with $1 \%$ crystal violet at room temperature for $20 \mathrm{~min}$; the plates were then rinsed with ample water and dried before photography and quantification.

\section{Calcium concentration}

The calcium concentrations in the growth media were determined using calcium concentration kit (Sigma), following the manufacturer's protocol.

RNA isolation, reverse transcription and realtime quantitative polymerase chain reaction (RT-PCR) 
Total RNA was isolated from cultured cells using PureLink RNA Mini Kit (Invitrogen). Reverse transcription was performed using SuperScript III reverse transcriptase (Invitrogen). RT-PCR was carried out with an Agilent Technologies Stratagene Mx3000P PCR machine using PowerUp SYBR Green Master Mix (Applied Biosystems) as the detection format. The reactions were cycled 40 times under the appropriate parameters for each pair of primers and fluorescence was measured at the end of each cycle to construct the amplification curve. All determinations were performed at least in triplicate. The primer sequences are included in Table S1.

\section{Western blot analyses}

The wild type and $M a p 3 k 1^{\triangle K D / \triangle K D}$ keratinocytes maintained in KSFM-Ca ${ }^{2+}$ or switched to DKSFM for 2 days were starved overnight in corresponding media without growth factor (GF). Cells were treated with $10 \mathrm{uM} \mathrm{S1P}$ and $10 \mathrm{uM} \mathrm{LPA}$ in GF-free media for $30 \mathrm{~min}$, and then lysed in RIPA buffer (150 mM NaCl, 1\% Nonidet P-40, 0.5\% sodium deoxycholate, $0.1 \%$ SDS, $50 \mathrm{mM}$ Tris, $\mathrm{pH}$ 7.4). The cell lysates were subjected to SDS-PAGE, transferred onto nitrocellulose membranes and probed with antibodies as described previously (13).

\section{Wound-healing assays.}

Wild type and Map $3 k 1^{4 K D / \Delta K D}$ keratinocytes were grown in $\mathrm{KSFM}^{-\mathrm{Ca}^{2+}}$ in 24-well collagen IVcoated plates. When reaching $80 \%$ confluence, some cells were maintained in $\mathrm{KSFM}-\mathrm{Ca}^{2+}$, and others had the medium changed to DKSFM for 2448 hours. Scratch wounds were created on the monolayer with a micropipette tip and wound healing was carried out in GF-free KSFM-Ca ${ }^{2+}$ or DKSFM medium in the presence or absence of 10 $\mu \mathrm{M} \mathrm{S1P}$. At 24 hours after healing, the wound area was photographed, and the speed of wound closure was calculated based on wound area differences at 0 and $24 \mathrm{~h}$. The wound closure rate was compared to that of untreated cells, defined as 1 .

\section{Immunofluorescence staining}

Cells were seeded on collagen IV-coated $6 \mathrm{~mm}$ glass coverslips and grown in KSFM-Ca ${ }^{2+}$. When reaching $80 \%$ confluence, the medium was changed to DKSFM and/or KSFM $+\mathrm{Ca}^{2+}$ for 24-72 hours. In some experiments, scratch wounds were created and wounds were allowed to heal for 6 hours. The cells were fixed and permeabilized and immunostaining was performed as described previously (96). Images were obtained using a Zeiss Axio microscope.

\section{Statistical Analyses}

Means and standard deviations were calculated from at least three independent experiments, and analyzed using student's t-test in which $p<0.05$ was considered statistically significant.

Data availability: These and all other data needed to evaluate the conclusions in the paper are present in the paper or the Supplementary Materials. All materials will be supplied upon request.

Acknowledgements. The authors would like to thank Drs. Alvaro Pug, University of Cincinnati, for critical reading, Drs. Laura Wolszon and Gwendolyn Kaeser, Sanford Burnham Prebys Medical Discovery Institute, for editing, and Dr. Yuhang Zhang, University of Cincinnati, for consultations.

Funding. Work described here is supported in part by NIH grants RO1EY15227 (YX), RO1HD098106 (YX) and a pilot project grant (YX) from P30ES006096 (JY). The content is solely the responsibility of the authors and does not necessarily represent the official views of the National Institutes of Health.

Conflict of interest. The authors declare that they have no conflicts of interest with the contents of this article

\section{References}


1. Karin, M. (1998) Mitogen-activated protein kinase cascades as regulators of stress responses. Ann N Y Acad Sci 851, 139-146

2. $\quad$ Craig, E. A., Stevens, M. V., Vaillancourt, R. R., and Camenisch, T. D. (2008) MAP3Ks as central regulators of cell fate during development. Dev. Dyn 237, 3102-3114

3. Geh, G. N., Jin, C., and Xia, Y. (2010) Map3k1. Nature Molecular Page

4. Su, F., Li, H., Yan, C., Jia, B., Zhang, Y., and Chen, X. (2009) Depleting MEKK1 expression inhibits the ability of invasion and migration of human pancreatic cancer cells. J. Cancer Res. Clin. Oncol

5. $\quad$ Deng, M., Chen, W. L., Takatori, A., Peng, Z., Zhang, L., Mongan, M., Parthasarathy, R., Sartor, M., Miller, M., Yang, J., Su, B., Kao, W. W., and Xia, Y. (2006) A role for the mitogen-activated protein kinase kinase kinase 1 in epithelial wound healing. Mol. Biol. Cell 17, 3446-3455

6. Labuda, T., Christensen, J. P., Rasmussen, S., Bonnesen, B., Karin, M., Thomsen, A. R., and Odum, N. (2006) MEK kinase 1 is a negative regulator of virus-specific CD8(+) T cells. Eur. J. Immunol 36, 2076-2084

7. Cuevas, B. D., Winter-Vann, A. M., Johnson, N. L., and Johnson, G. L. (2006) MEKK1 controls matrix degradation and tumor cell dissemination during metastasis of polyoma middle-T driven mammary cancer. Oncogene 25, 4998-5010

8. Li, Y., Minamino, T., Tsukamoto, O., Yujiri, T., Shintani, Y., Okada, K., Nagamachi, Y., Fujita, M., Hirata, A., Sanada, S., Asanuma, H., Takashima, S., Hori, M., Johnson, G. L., and Kitakaze, M. (2005) Ablation of MEK kinase 1 suppresses intimal hyperplasia by impairing smooth muscle cell migration and urokinase plasminogen activator expression in a mouse blood-flow cessation model. Circulation 111, 1672-1678

9. Bonnesen, B., Orskov, C., Rasmussen, S., Holst, P. J., Christensen, J. P., Eriksen, K. W., Qvortrup, K., Odum, N., and Labuda, T. (2005) MEK kinase 1 activity is required for definitive erythropoiesis in the mouse fetal liver. Blood 106, 3396-3404

10. Uhlik, M. T., Abell, A. N., Cuevas, B. D., Nakamura, K., and Johnson, G. L. (2004) Wiring diagrams of MAPK regulation by MEKK1, 2, and 3. Biochem. Cell Biol 82, 658-663

11. Xia, Y., and Kao, W. W. (2004) The signaling pathways in tissue morphogenesis: a lesson from mice with eye-open at birth phenotype. Biochem. Pharmacol 68, 997-1001

12. Yujiri, T., Sather, S., Fanger, G. R., and Johnson, G. L. (1998) Role of MEKK1 in cell survival and activation of JNK and ERK pathways defined by targeted gene disruption. Science 282, 1911-1914

13. Zhang, L., Wang, W., Hayashi, Y., Jester, J. V., Birk, D. E., Gao, M., Liu, C. Y., Kao, W. W., Karin, M., and Xia, Y. (2003) A role for MEK kinase 1 in TGF-beta/activin-induced epithelium movement and embryonic eyelid closure. Embo J 22, 4443-4454

14. Juriloff, D. M., Harris, M. J., and Mah, D. G. (2005) The open-eyelid mutation, lidgap-Gates, is an eight-exon deletion in the mouse Map3k1 gene. Genomics 85, 139-142

15. Byun, T. H., Kim, J. T., Park, H. W., and Kim, W. K. (2011) Timetable for upper eyelid development in staged human embryos and fetuses. Anat. Rec. (Hoboken. ) 294, 789-796

16. Barishak, Y. R. (1992) Embryology of the eye and its adnexae. Dev Ophthalmol 24, 1-142

17. Harris, M. J., and Juriloff, D. M. (1986) Eyelid development and fusion induced by cortisone treatment in mutant, lidgap-Miller, foetal mice. A scanning electron microscope study. J Embryol Exp Morphol 91, 1-18

18. Tao, H., Ono, K., Kurose, H., Noji, S., and Ohuchi, H. (2006) Exogenous FGF10 can rescue an eye-open at birth phenotype of Fgf10-null mice by activating activin and TGFalpha-EGFR signaling. Dev. Growth Differ 48, 339-346

19. Rubinstein, T. J., Weber, A. C., and Traboulsi, E. I. (2016) Molecular biology and genetics of embryonic eyelid development. Ophthalmic Genet, 1-8

20. De Moerlooze, L., Spencer-Dene, B., Revest, J., Hajihosseini, M., Rosewell, I., and Dickson, C. (2000) An important role for the IIIb isoform of fibroblast growth factor receptor 2 (FGFR2) in mesenchymal-epithelial signalling during mouse organogenesis. Development 127, 483-492 
21. Behrens, A., Sibilia, M., and Wagner, E. F. (1999) Amino-terminal phosphorylation of c-Jun regulates stress-induced apoptosis and cellular proliferation. Nat. Genet 21, 326-329

22. Threadgill, D. W., Dlugosz, A. A., Hansen, L. A., Tennenbaum, T., Lichti, U., Yee, D., LaMantia, C., Mourton, T., Herrup, K., Harris, R. C., and al., e. (1995) Targeted disruption of mouse EGF receptor: effect of genetic background on mutant phenotype. Science 269, 230-234

23. Heller, E., Kumar, K. V., Grill, S. W., and Fuchs, E. (2014) Forces generated by cell intercalation tow epidermal sheets in Mammalian tissue morphogenesis. Dev. Cell 28, 617-632

24. Xia, Y., Makris, C., Su, B., Li, E., Yang, J., Nemerow, G. R., and Karin, M. (2000) MEK kinase 1 is critically required for c-Jun $\mathrm{N}$-terminal kinase activation by proinflammatory stimuli and growth factor-induced cell migration. Proc. Natl. Acad. Sci. U. S. A 97, 5243-5248

25. Yan, M., Dai, T., Deak, J. C., Kyriakis, J. M., Zon, L. I., Woodgett, J. R., and Templeton, D. J. (1994) Activation of stress-activated protein kinase by MEKK1 phosphorylation of its activator SEK1. Nature 372, 798-800

26. Takatori, A., Geh, E., Chen, L., Zhang, L., Meller, J., and Xia, Y. (2008) Differential transmission of MEKK1 morphogenetic signals by JNK1 and JNK2. Development 135, 23-32

27. Geh, E., Meng, Q., Mongan, M., Wang, J., Takatori, A., Zheng, Y., Puga, A., Lang, R. A., and Xia, Y. (2011) Mitogen-activated protein kinase kinase kinase 1 (MAP3K1) integrates developmental signals for eyelid closure. Proc. Natl. Acad. Sci. U. S. A 108, 17349-17354

28. Zhang, L., Deng, M., Parthasarathy, R., Wang, L., Mongan, M., Molkentin, J. D., Zheng, Y., and Xia, Y. (2005) MEKK1 transduces activin signals in keratinocytes to induce actin stress fiber formation and migration. Mol. Cell Biol 25, 60-65

29. Sternweis, P. C., Carter, A. M., Chen, Z., Danesh, S. M., Hsiung, Y. F., and Singer, W. D. (2007) Regulation of Rho guanine nucleotide exchange factors by G proteins. Adv Protein Chem 74, 189228

30. Aarthi, J. J., Darendeliler, M. A., and Pushparaj, P. N. (2011) Dissecting the role of the S1P/S1PR axis in health and disease. $J$ Dent Res 90, 841-854

31. Kihara, Y., Maceyka, M., Spiegel, S., and Chun, J. (2014) Lysophospholipid receptor nomenclature review: IUPHAR Review 8. Br J Pharmacol 171, 3575-3594

32. Chun, J., Kihara, Y., Jonnalagadda, D., and Blaho, V. A. (2019) Fingolimod: Lessons Learned and New Opportunities for Treating Multiple Sclerosis and Other Disorders. Annu Rev Pharmacol Toxicol 59, 149-170

33. Ishii, I., Fukushima, N., Ye, X., and Chun, J. (2004) Lysophospholipid receptors: signaling and biology. Аnnu Rev Biochem 73, 321-354

34. Bjarnadottir, T. K., Gloriam, D. E., Hellstrand, S. H., Kristiansson, H., Fredriksson, R., and Schioth, H. B. (2006) Comprehensive repertoire and phylogenetic analysis of the $G$ protein-coupled receptors in human and mouse. Genomics $\mathbf{8 8}, 263-273$

35. Lopez-Ilasaca, M. (1998) Signaling from G-protein-coupled receptors to mitogen-activated protein (MAP)-kinase cascades. Biochem Pharmacol 56, 269-277

36. Herr, D. R., Lee, C. W., Wang, W., Ware, A., Rivera, R., and Chun, J. (2013) Sphingosine 1phosphate receptors are essential mediators of eyelid closure during embryonic development. $J$. Biol. Chem 288, 29882-29889

37. Rheinwald, J. G., and Green, H. (1975) Serial cultivation of strains of human epidermal keratinocytes: the formation of keratinizing colonies from single cells. Cell 6, 331-343

38. Rouabhia, M., Germain, L., Belanger, F., Guignard, R., and Auger, F. A. (1992) Optimization of murine keratinocyte culture for the production of graftable epidermal sheets. J. Dermatol 19, 325334

39. Rosenthal, D. S., Steinert, P. M., Chung, S., Huff, C. A., Johnson, J., Yuspa, S. H., and Roop, D. R. (1991) A human epidermal differentiation-specific keratin gene is regulated by calcium but not negative modulators of differentiation in transgenic mouse keratinocytes. Cell Growth Differ 2, $107-113$ 
40. Fusenig, N. E., and Worst, P. K. (1975) Mouse epidermal cell cultures. II. Isolation, characterization and cultivation of epidermal cells from perinatal mouse skin. Exp Cell Res 93, 443457

41. Morris, R. J., Haynes, A. C., Fischer, S. M., and Slaga, T. J. (1991) Concomitant proliferation and formation of a stratified epithelial sheet by explant outgrowth of epidermal keratinocytes from adult mice. In Vitro Cell Dev Biol 27A, 886-895

42. Lichti, U., Anders, J., and Yuspa, S. H. (2008) Isolation and short-term culture of primary keratinocytes, hair follicle populations and dermal cells from newborn mice and keratinocytes from adult mice for in vitro analysis and for grafting to immunodeficient mice. Nat Protoc 3, 799-810

43. Li, F., Adase, C. A., and Zhang, L. J. (2017) Isolation and Culture of Primary Mouse Keratinocytes from Neonatal and Adult Mouse Skin. $J$ Vis Exp

44. Barrandon, Y., and Green, H. (1987) Three clonal types of keratinocyte with different capacities for multiplication. Proc Natl Acad Sci U S A 84, 2302-2306

45. Blanpain, C., Lowry, W. E., Geoghegan, A., Polak, L., and Fuchs, E. (2004) Self-renewal, multipotency, and the existence of two cell populations within an epithelial stem cell niche. Cell 118, 635-648

46. Morris, R. J., Liu, Y., Marles, L., Yang, Z., Trempus, C., Li, S., Lin, J. S., Sawicki, J. A., and Cotsarelis, G. (2004) Capturing and profiling adult hair follicle stem cells. Nat Biotechnol 22, 411417

47. Michel, M., Torok, N., Godbout, M. J., Lussier, M., Gaudreau, P., Royal, A., and Germain, L. (1996) Keratin 19 as a biochemical marker of skin stem cells in vivo and in vitro: keratin 19 expressing cells are differentially localized in function of anatomic sites, and their number varies with donor age and culture stage. J Cell Sci 109 ( Pt 5), 1017-1028

48. Jensen, U. B., Yan, X., Triel, C., Woo, S. H., Christensen, R., and Owens, D. M. (2008) A distinct population of clonogenic and multipotent murine follicular keratinocytes residing in the upper isthmus. J Cell Sci 121, 609-617

49. Pellegrini, G., Dellambra, E., Golisano, O., Martinelli, E., Fantozzi, I., Bondanza, S., Ponzin, D., McKeon, F., and De Luca, M. (2001) p63 identifies keratinocyte stem cells. Proc Natl Acad Sci U $S$ A 98, 3156-3161

50. Tani, H., Morris, R. J., and Kaur, P. (2000) Enrichment for murine keratinocyte stem cells based on cell surface phenotype. Proc Natl Acad Sci U S A 97, 10960-10965

51. Li, A., Simmons, P. J., and Kaur, P. (1998) Identification and isolation of candidate human keratinocyte stem cells based on cell surface phenotype. Proc Natl Acad Sci U S A 95, 3902-3907

52. Vogelmann, R., Amieva, M. R., Falkow, S., and Nelson, W. J. (2004) Breaking into the epithelial apical-junctional complex--news from pathogen hackers. Curr Opin Cell Biol 16, 86-93

53. Xia, Y., Makris, C., Su, B., Li, E., Yang, J., Nemerow, G. R., and Karin, M. (2000) MEK kinase 1 is critically required for c-Jun $\mathrm{N}$-terminal kinase activation by proinflammatory stimuli and growth factor-induced cell migration. Proc Natl Acad Sci U S A 97, 5243-5248

54. Hla, T., and Brinkmann, V. (2011) Sphingosine 1-phosphate (S1P): Physiology and the effects of S1P receptor modulation. Neurology 76, S3-S8

55. Yook, K. J., Proulx, S. R., and Jorgensen, E. M. (2001) Rules of nonallelic noncomplementation at the synapse in Caenorhabditis elegans. Genetics 158, 209-220

56. Fisher, P. B., Lee, L. S., and Weinstein, I. B. (1980) Changes in epidermal growth factor receptors associated with adenovirus transformation, chemical carcinogen transformation and exposure to a phorbol ester tumor promoter. Biochem Biophys Res Commun 93, 1160-1166

57. Bertolero, F., Kaighn, M. E., Camalier, R. F., and Saffiotti, U. (1986) Effects of serum and serumderived factors on growth and differentiation of mouse keratinocytes. In Vitro Cell Dev Biol 22, 423-428

58. Bickenbach, J. R., and Chism, E. (1998) Selection and extended growth of murine epidermal stem cells in culture. Exp Cell Res 244, 184-195 
59. Hager, B., Bickenbach, J. R., and Fleckman, P. (1999) Long-term culture of murine epidermal keratinocytes. J Invest Dermatol 112, 971-976

60. Tudor, D., Chaudry, F., Harper, L., and Mackenzie, I. C. (2007) The in vitro behaviour and patterns of colony formation of murine epithelial stem cells. Cell Prolif 40, 706-720

61. Leblond, C. P. (1964) Classification of Cell Populations on the Basis of Their Proliferative Behavior. Natl Cancer Inst Monogr 14, 119-150

62. Hennings, H., Michael, D., Cheng, C., Steinert, P., Holbrook, K., and Yuspa, S. H. (1980) Calcium regulation of growth and differentiation of mouse epidermal cells in culture. Cell 19, 245-254

63. Potten, C. S. (1974) The epidermal proliferative unit: the possible role of the central basal cell. Cell Tissue Kinet 7, 77-88

64. Alcolea, M. P., and Jones, P. H. (2014) Lineage analysis of epidermal stem cells. Cold Spring Harb Perspect Med 4, a015206

65. Clayton, E., Doupe, D. P., Klein, A. M., Winton, D. J., Simons, B. D., and Jones, P. H. (2007) A single type of progenitor cell maintains normal epidermis. Nature 446, 185-189

66. Roy, E., Neufeld, Z., Cerone, L., Wong, H. Y., Hodgson, S., Livet, J., and Khosrotehrani, K. (2016) Bimodal behaviour of interfollicular epidermal progenitors regulated by hair follicle position and cycling. EMBO J 35, 2658-2670

67. Gallagher, E. D., Gutowski, S., Sternweis, P. C., and Cobb, M. H. (2003) RhoA binds to the aminoterminus of MEKK1 and regulates its kinase activity. J. Biol. Chem

68. Contos, J. J., Fukushima, N., Weiner, J. A., Kaushal, D., and Chun, J. (2000) Requirement for the lpA1 lysophosphatidic acid receptor gene in normal suckling behavior. Proc Natl Acad Sci U S A 97, 13384-13389

69. Chan, L. C., Peters, W., Xu, Y., Chun, J., Farese, R. V., Jr., and Cases, S. (2007) LPA3 receptor mediates chemotaxis of immature murine dendritic cells to unsaturated lysophosphatidic acid (LPA). J Leukoc Biol 82, 1193-1200

70. Lee, Z., Cheng, C. T., Zhang, H., Subler, M. A., Wu, J., Mukherjee, A., Windle, J. J., Chen, C. K., and Fang, X. (2008) Role of LPA4/p2y9/GPR23 in negative regulation of cell motility. Mol Biol Cell 19, 5435-5445

71. Lin, M. E., Rivera, R. R., and Chun, J. (2012) Targeted deletion of LPA5 identifies novel roles for lysophosphatidic acid signaling in development of neuropathic pain. J Biol Chem 287, 1760817617

72. Cvekl, A., and Duncan, M. K. (2007) Genetic and epigenetic mechanisms of gene regulation during lens development. Prog. Retin. Eye Res 26, 555-597

73. Ponnusamy, S., Selvam, S. P., Mehrotra, S., Kawamori, T., Snider, A. J., Obeid, L. M., Shao, Y., Sabbadini, R., and Ogretmen, B. (2012) Communication between host organism and cancer cells is transduced by systemic sphingosine kinase 1/sphingosine 1-phosphate signalling to regulate tumour metastasis. EMBO Mol Med 4, 761-775

74. Sukocheva, O., Wadham, C., and Xia, P. (2013) Estrogen defines the dynamics and destination of transactivated EGF receptor in breast cancer cells: role of S1P(3) receptor and Cdc42. Exp Cell Res 319, 455-465

75. Herr, D. R., Grillet, N., Schwander, M., Rivera, R., Muller, U., and Chun, J. (2007) Sphingosine 1phosphate (S1P) signaling is required for maintenance of hair cells mainly via activation of S1P2. J Neurosci 27, 1474-1478

76. Kono, M., Belyantseva, I. A., Skoura, A., Frolenkov, G. I., Starost, M. F., Dreier, J. L., Lidington, D., Bolz, S. S., Friedman, T. B., Hla, T., and Proia, R. L. (2007) Deafness and stria vascularis defects in S1P2 receptor-null mice. J. Biol. Chem 282, 10690-10696

77. Yousaf, R., Meng, Q., Hufnagel, R. B., Xia, Y., Puligilla, C., Ahmed, Z. M., and Riazuddin, S. (2015) MAP3K1 function is essential for cytoarchitecture of the mouse organ of Corti and survival of auditory hair cells. Dis. Model. Mech 8, 1543-1553 
78. Smeal, T., Binetruy, B., Mercola, D., Grover-Bardwick, A., Heidecker, G., Rapp, U. R., and Karin, M. (1992) Oncoprotein-mediated signalling cascade stimulates c-Jun activity by phosphorylation of serines 63 and 73. Mol. Cell Biol 12, 3507-3513

79. Franklin, C. C., Sanchez, V., Wagner, F., Woodgett, J. R., and Kraft, A. S. (1992) Phorbol esterinduced amino-terminal phosphorylation of human JUN but not JUNB regulates transcriptional activation. Proc. Natl. Acad. Sci. U. S. A 89, 7247-7251

80. Karin, M., Liu, Z., and Zandi, E. (1997) AP-1 function and regulation. Curr Opin Cell Biol 9, 240246

81. Li, G., Gustafson-Brown, C., Hanks, S. K., Nason, K., Arbeit, J. M., Pogliano, K., Wisdom, R. M., and Johnson, R. S. (2003) c-Jun Is Essential for Organization of the Epidermal Leading Edge. Dev. Cell 4, 865-877

82. Zenz, R., Scheuch, H., Martin, P., Frank, C., Eferl, R., Kenner, L., Sibilia, M., and Wagner, E. F. (2003) c-Jun Regulates Eyelid Closure and Skin Tumor Development through EGFR Signaling. Dev. Cell 4, 879-889

83. Tokumaru, S., Higashiyama, S., Endo, T., Nakagawa, T., Miyagawa, J. I., Yamamori, K., Hanakawa, Y., Ohmoto, H., Yoshino, K., Shirakata, Y., Matsuzawa, Y., Hashimoto, K., and Taniguchi, N. (2000) Ectodomain shedding of epidermal growth factor receptor ligands is required for keratinocyte migration in cutaneous wound healing. J Cell Biol 151, 209-220

84. Fu, S., Bottoli, I., Goller, M., and Vogt, P. K. (1999) Heparin-binding epidermal growth factor-like growth factor, a v-Jun target gene, induces oncogenic transformation. Proc Natl Acad Sci U S A 96, 5716-5721

85. Behrens, A., Haigh, J., Mechta-Grigoriou, F., Nagy, A., Yaniv, M., and Wagner, E. F. (2003) Impaired intervertebral disc formation in the absence of Jun. Development 130, 103-109

86. Meng, Q., Mongan, M., Wang, J., Tang, X., Zhang, J., Kao, W., and Xia, Y. (2014) Epithelial sheet movement requires the cooperation of c-Jun and MAP3K1. Dev. Biol

87. Huang, C., Rajfur, Z., Borchers, C., Schaller, M. D., and Jacobson, K. (2003) JNK phosphorylates paxillin and regulates cell migration. Nature 424, 219-223

88. Small, J. V., Stradal, T., Vignal, E., and Rottner, K. (2002) The lamellipodium: where motility begins. Trends Cell Biol 12, 112-120

89. Meng, Q., Mongan, M., Carreira, V., Kurita, H., Liu, C. Y., Kao, W., and Xia, Y. (2014) Eyelid closure in embryogenesis is required for ocular adnexa development. Invest Ophthalmol. Vis. Sci

90. Wang, J., Call, M., Mongan, M., Kao, W. W., and Xia, Y. (2017) Meibomian gland morphogenesis requires developmental eyelid closure and lid fusion. Ocul Surf

91. Kennedy, D. P., Chandler, J. W., and McCulley, J. P. (2015) Ocular surface involvements in ectrodactyly-ectodermal dysplasia-cleft syndrome. Cont Lens Anterior Eye 38, 228-231

92. Lorenz, B. (2002) Genetics of isolated and syndromic strabismus: facts and perspectives. Strabismus 10, 147-156

93. Oystreck, D. T., and Lyons, C. J. (2012) Comitant strabismus: Perspectives, present and future. Saudi. J. Ophthalmol 26, 265-270

94. Finsterer, J. (2003) Ptosis: causes, presentation, and management. Aesthetic Plast. Surg 27, 193204

95. Mongan, M., Meng, Q., Wang, J., Kao, W. W., Puga, A., and Xia, Y. (2015) Gene-Environment Interactions Target Mitogen-activated Protein 3 Kinase 1 (MAP3K1) Signaling in Eyelid Morphogenesis. J. Biol. Chem 290, 19770-19779

96. Nobes, C. D., and Hall, A. (1999) Rho GTPases control polarity, protrusion, and adhesion during cell movement. J. Cell Biol 144, 1235-1244 
bioRxiv preprint doi: https://doi.org/10.1101/2020.06.23.167304; this version posted June 23, 2020. The copyright holder for this preprint (which was not certified by peer review) is the author/funder, who has granted bioRxiv a license to display the preprint in perpetuity. It is made available under aCC-BY-NC-ND 4.0 International license.

Table 1. Cultured Murine Epithelial Lines

\begin{tabular}{c|c}
\hline Cell lines & Colony forming efficiency $(\%)$ \\
\hline 1 & 0.48 \\
2 & 0.69 \\
3 & 1.4 \\
4 & 2.9 \\
5 & 3.75 \\
6 & 5.93 \\
\hline
\end{tabular}




\section{Figures}
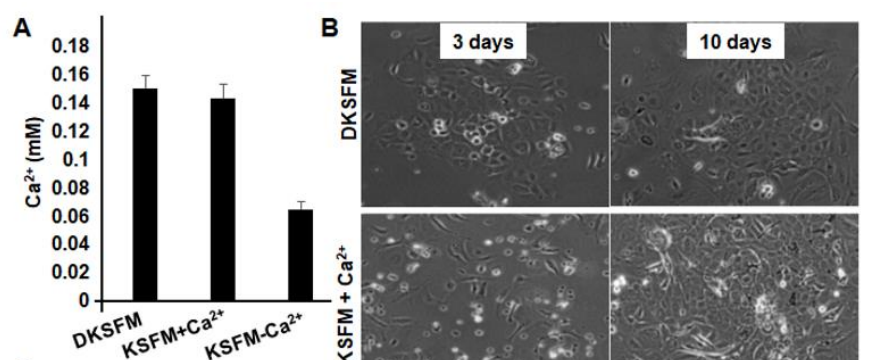

C
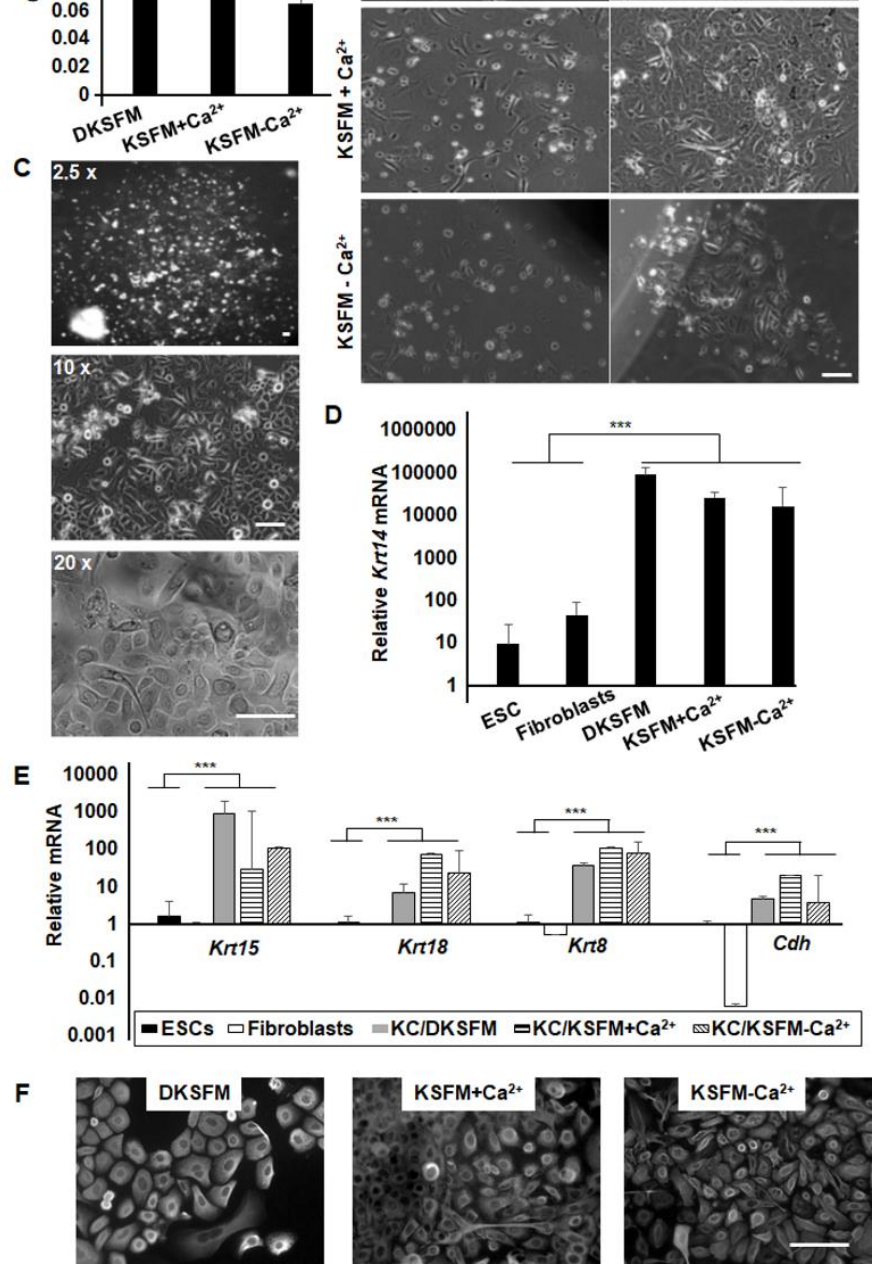

Figure 1. Culture conditions of the mouse keratinocytes. (A) The calcium concentrations in three commercial keratinocyte growth media. (B) Bright-field microscopic images of cells grown for 3 or 10 days in culture. (C) Images of colonies of cells grown in KSFM-Ca ${ }^{2+}$ medium for an extended period of time. The expression levels of keratinocyte-specific genes (D) Krt14 and (E) Krt8, Krt15, Krt18 and Cdh, were determined by RT-PCR. Expression in cells grown in the three types of KSFM medium was compared to that in ESCs and fibroblasts. (F) Cells were subjected to immunofluorescence staining with anti-K14 and photographed under fluorescent microscope. Results represent data from at least three duplicate experiments $+/-\mathrm{SD}$, and $* * * \mathrm{p}<0.001$ was considered significant. The scale bars in microscope image correspond to $100 \mu \mathrm{m}$. 

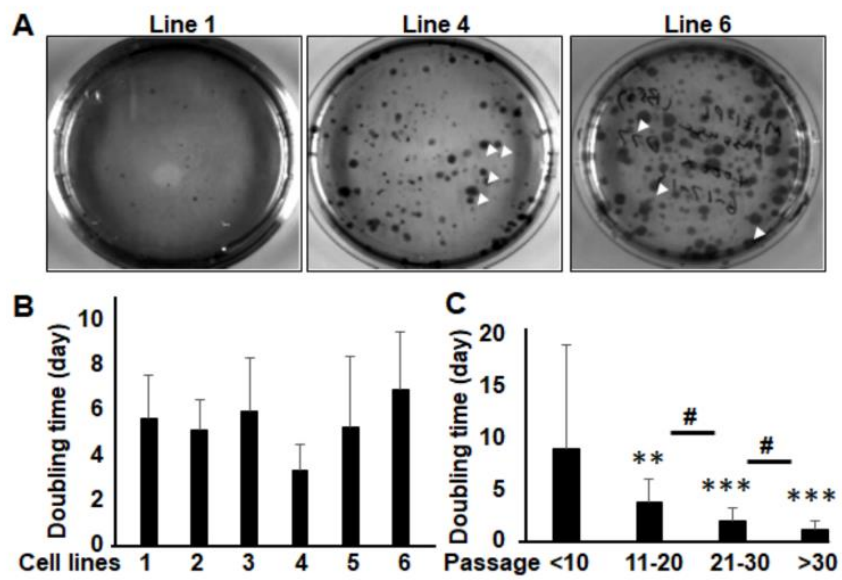

Figure 2. The growth properties of long-term keratinocyte culture. (A) Representative photos of colonies formed with different keratinocyte lines derived in $\mathrm{KSFM}_{-} \mathrm{Ca}^{2+}$, with varied colony-forming efficiency. Arrowheads indicate at representative holoclones. The average doubling time of (B) each cell line, and $(\mathrm{C})$ all lines at different passages, calculated based on the cell counts upon passaging and days of growth $+/$-SD. The doubling time of medium and high passages was significantly reduced relative to that of low passages $(* * \mathrm{p}<0.01$ and $* * * \mathrm{p}<0.001)$. Similarly, cells at $>30$ passages grew much faster than at 21 30 passages, which in turn grew faster than at $11-20$ passages $(\# \mathrm{p}<0.01)$. 


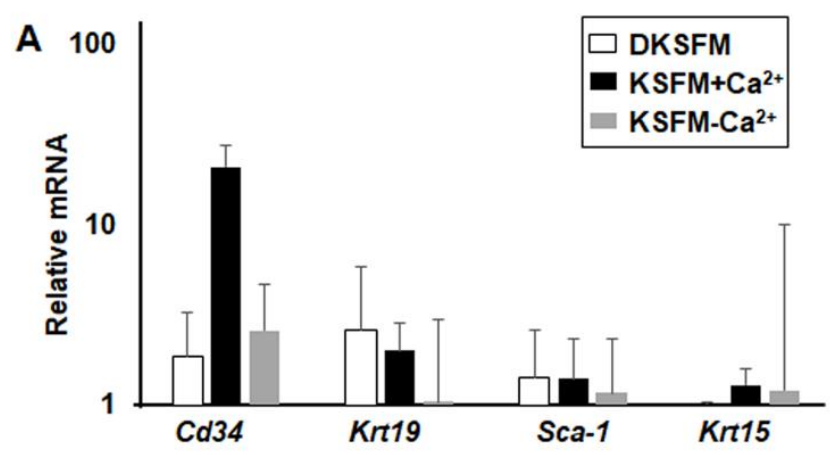

C

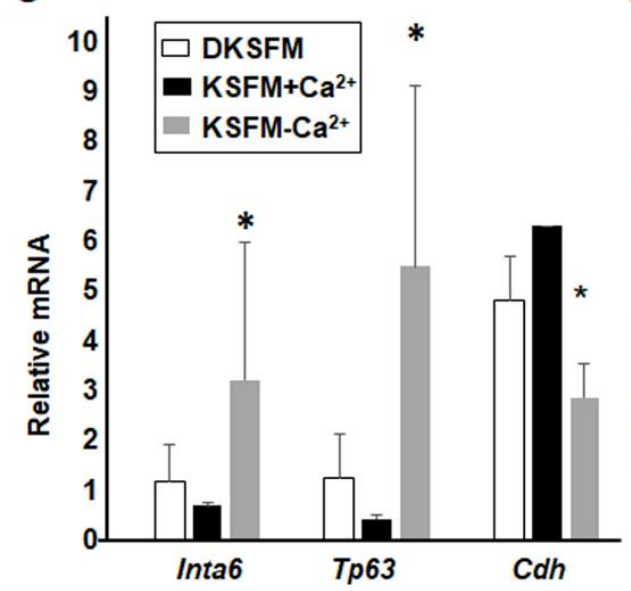

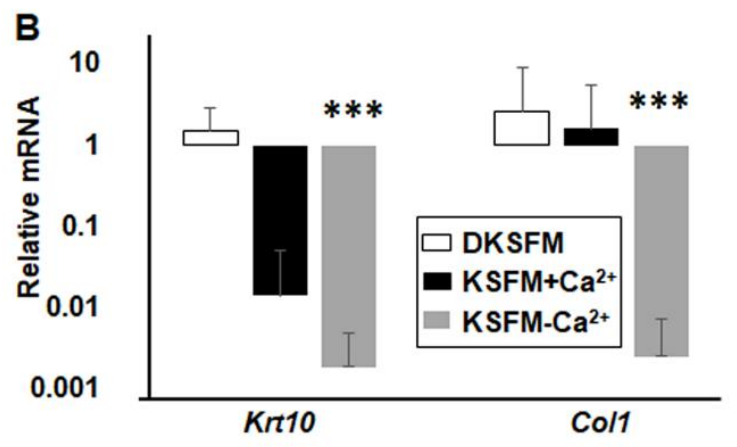
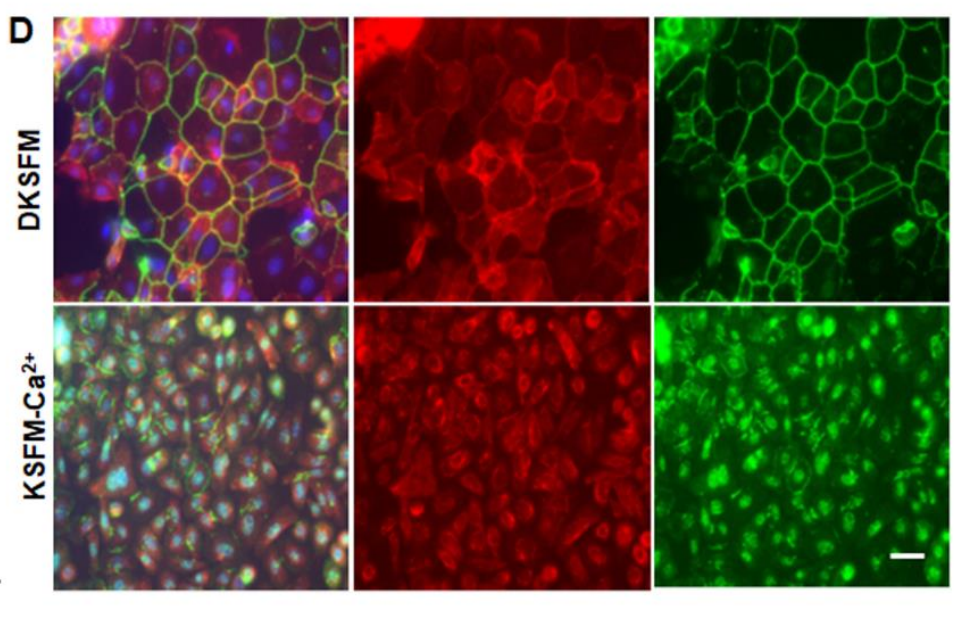

Figure 3. The molecular characteristics of long-term keratinocyte culture. mRNA isolated from primary keratinocytes in DKSFM and KSFM+Ca ${ }^{2+}$, as well as long-term cultured keratinocytes in KSFM$\mathrm{Ca}^{2+}$, was examined by RT-PCR for expression of markers of: (A) epidermal stem cells and progenitors (Cd34, Krt19, Sca-1 and Krt15), (B) epidermal terminal differentiation (Krt10 and Coll), and (C) epithelial cell proliferation (Inta6 and Tp63) and cell-cell junctions (Cdh). (D) Immunofluorescence staining for ECadherin and ZO-1, which were located on plasma membrane at cell-cell contacts in cells grown in DKSFM, but were mostly detected in the nucleus and/or cytosol in the long-term keratinocyte in KSFM$\mathrm{Ca}^{2+}$. The scale bars in microscope images correspond to $100 \mu \mathrm{m}$. Error bars represent Mean +/- SD *p<0.05 and $* * * p<0.001$ are considered significantly different from values in cells grown in DKSFM. 


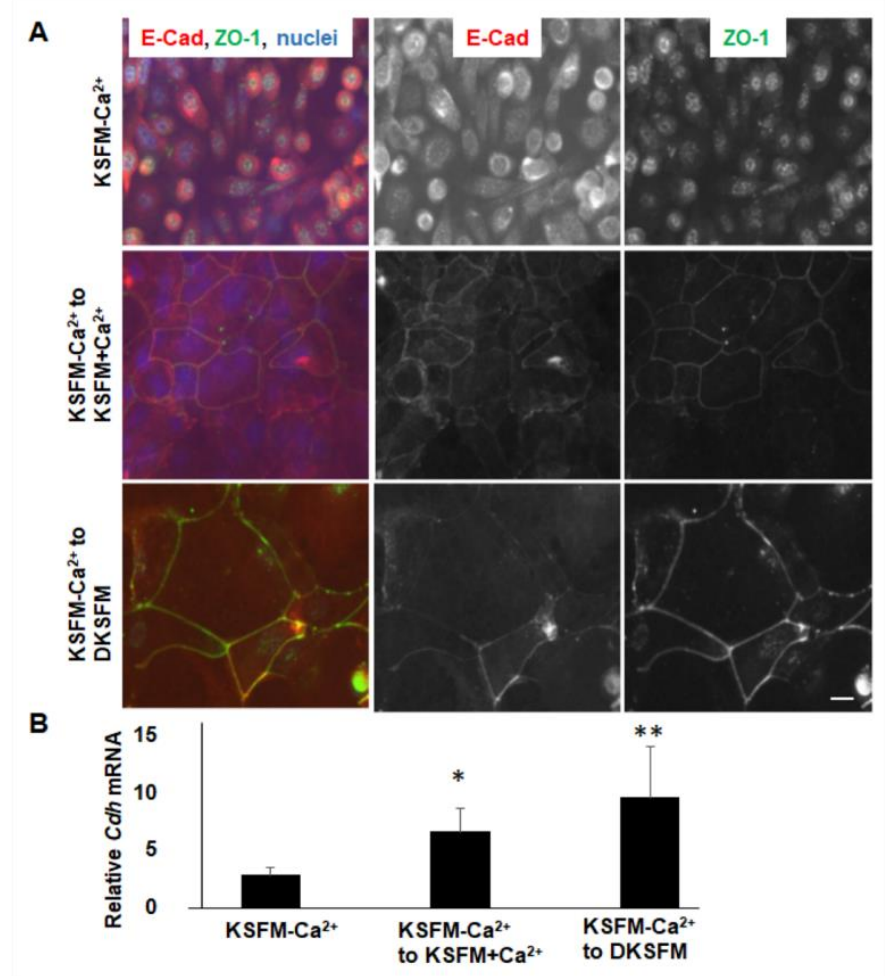

Figure 4. Restoration of cell-cell junctions in long-term cultured keratinocytes. Cells in KSFM-Ca ${ }^{2+}$ with or without switching to DKSFM or $\mathrm{KSFM}+\mathrm{Ca}^{2+}$ for $48 \mathrm{~h}$ were examined by (A) immunofluorescence staining for E-Cadherin and ZO-1, and (B) RT-PCR for the expression of $C d h(\mathrm{~N}=3)+/$-SD. Replacing the medium with DKSFM or KSFM+Ca ${ }^{2+}$ restored the formation of adherens junctions and tight junctions and significantly increased E-cadherin expression $(* \mathrm{p}<0.05, * * \mathrm{p}<0.01)$. Scale bar represents $20 \mu \mathrm{m}$. 

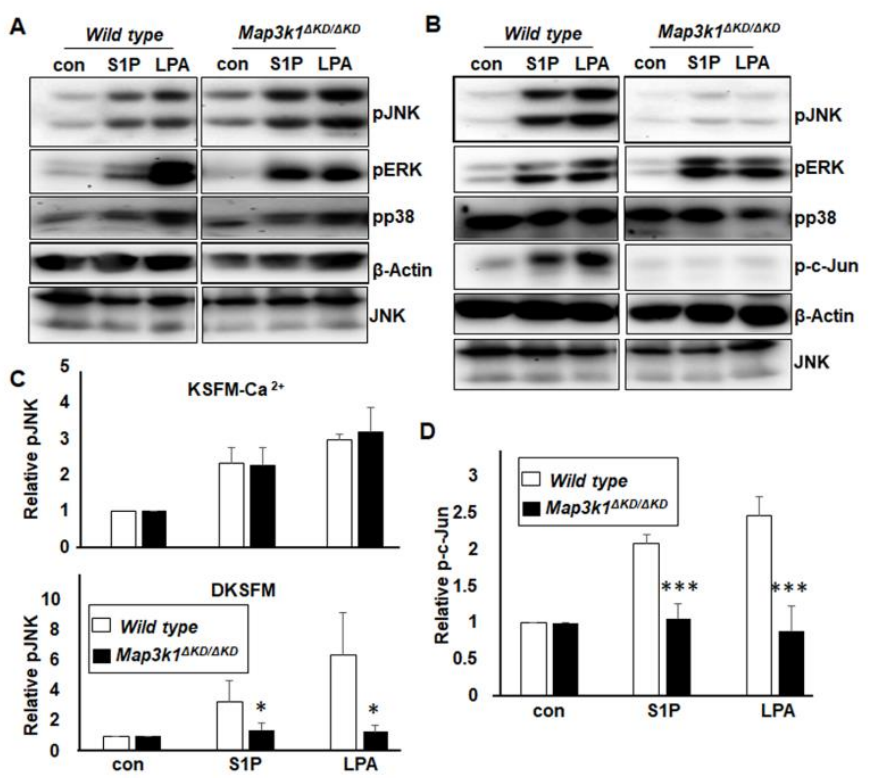

Figure 5. S1P activates the MAP3K1-JNK pathway in basal epithelial cells. The keratinocyte lines derived from wild type and Map3k $1^{4 K D / \triangle K D}$ pups were either (A) maintained in KSFM-Ca ${ }^{2+}$ or (B) switched to DKSFM for $48 \mathrm{~h}$. After starvation overnight in growth factor-free media, cells were treated with S1P $(10 \mu \mathrm{M})$ and LPA $(10 \mu \mathrm{M})$ for $30 \mathrm{~min}$, and cell lysates analyzed by Western blotting using the antibodies indicated. The relative levels of (C) $\mathrm{pJNK}$, and (D) $\mathrm{p}$-c-Jun versus $\beta$-Actin were calculated based on signal intensity determined with the gel documentation system. In cells switched to DKSFM, the induction of pJNK and p-c-Jun was more abundant in wild type than in Map $3 k 1^{4 K D / \triangle K D}$ cells. Results represent data from at least 5 independent experiments $+/-\mathrm{SD} * \mathrm{p}<0.05$, and $* * * \mathrm{p}<0.001$. 


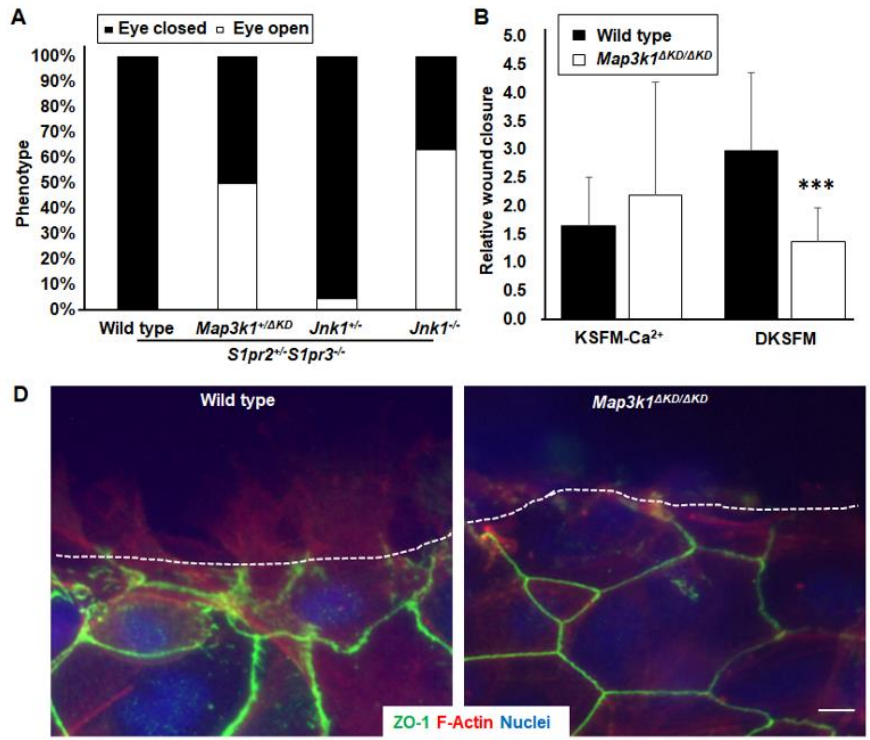

Figure 6. The S1P-MAP3K1 pathway in epithelial cell movement and eyelid closure. (A) Genetic crossing of the $S 1 p 2 / 3$-mutant with the Map3kl-and the Jnkl-mutant mice. The eye open phenotype in the offspring of the indicated genotypes was recorded. A total of $19 \mathrm{Slpr}^{+/-} \mathrm{Slpr}^{{ }^{-/}}, 6 \mathrm{Slpr}^{+/-} \mathrm{SIpr}^{-/-} \mathrm{Map} 3 \mathrm{kI}^{+/}$

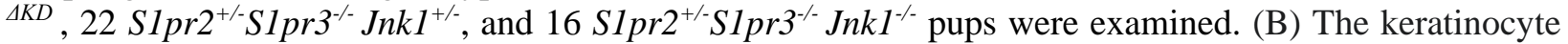
lines derived from wild type and Map3k $1^{\triangle K D / \triangle K D}$ pups were either maintained in KSFM-Ca ${ }^{2+}$ or switched to DKSFM for $48 \mathrm{~h}$, and the confluent culture was subjected to in vitro wound-healing assays. The wounds were photographed at 0 and $24 \mathrm{~h}$, when wound sizes were measured and wound-closure distances calculated. Results represent at least 6 independent experiments with 8 data sets in each experiment +/- SD. Compared to that of the wild type cells, the movement of the Map3k1 ${ }^{\triangle K D}$ cells in the DKSFM was decreased $* * * p<0.001$. (D) $6 \mathrm{~h}$ after wounding, keratinocytes grown in the DKSFM were fixed, permeabilized and subjected to immunofluorescence staining for ZO-1, phalloidin (F-actin) and Hoechst 33258 (nucleus). The wounding edge was photographed under the fluorescence microscope. Dotted lines mark the leading edge of the wound, scale bar represents $20 \mu \mathrm{m}$. 